\title{
Corticotropin-releasing hormone receptor expression and functional signaling in murine gonadotrope-like cells
}

\author{
Audrey F Seasholtz ${ }^{1,2}$, Miina Öhman ${ }^{3}$, Amale Wardani ${ }^{1}$ and Robert C Thompson ${ }^{1,3}$ \\ ${ }^{1}$ Molecular and Behavioral Neuroscience Institute ${ }^{2}$ Department of Biological Chemistry and ${ }^{3}$ Department of Psychiatry, University of Michigan, 109 Zina Pitcher \\ Place, BSRB Room 5035, Ann Arbor, Michigan 48109, USA \\ (Correspondence should be addressed to A F Seasholtz; Email: aseashol@umich.edu) \\ (M Öhman is now at Department of Internal Medicine, Cardiology, University of Michigan, Ann Arbor, Michigan, USA)
}

\begin{abstract}
Corticotropin-releasing hormone $(\mathrm{CRH})$ is a key regulator of the mammalian stress response, mediating a wide variety of stress-associated behaviors including stress-induced inhibition of reproductive function. To investigate the potential direct action of CRH on pituitary gonadotrope function, we examined $\mathrm{CRH}$ receptor expression and second messenger signaling in $\alpha \mathrm{T} 3-1$ cells, a murine gonadotrope-like cell line. Reverse transcriptase PCR (RT-PCR) studies demonstrated that $\alpha \mathrm{T} 3-1$ cells express mRNA for the two CRH receptor subtypes, CRHR 1 and CRHR2, with CRHR2 $\alpha$ as the predominant CRHR2 isoform. Stimulation of the cells with $\mathrm{CRH}$ or urocortin (UCN) resulted in rapid, transient increases in the intracellular levels of cAMP that were completely blocked by the addition of $\alpha$-helical CRH 9-41 or astressin, non-selective $\mathrm{CRH}$ receptor antagonists. Stimulation of the cells with CRHR2-specific ligands,
\end{abstract}

urocortin 2 (UCN2) or urocortin 3 (UCN3), resulted in rapid increases in intracellular cAMP levels to $50-60 \%$ of the levels observed with UCN. Treatment with a selective CRHR2 antagonist, antisauvagine, completely blocked UCN3-mediated increases in cAMP and significantly reduced, but did not completely block UCN-mediated increases in cAMP, demonstrating that both CRHR1 and CRHR2 are functionally active in these gonadotrope-like cells. Finally, UCN treatment significantly increased the transcriptional activity of the glycoprotein hormone $\alpha$-subunit promoter as assessed by $\alpha$-luciferase transfection assays. Together, these results demonstrate the functional signaling of CRH receptors in $\alpha \mathrm{T} 3-1$ cells, suggesting that $\mathrm{CRH}$ may also modulate pituitary gonadotrope function in vivo.

Journal of Endocrinology (2009) 200, 223-232

\section{Introduction}

Corticotropin-releasing hormone $(\mathrm{CRH})$ is a key regulator of the endocrine, behavioral, and autonomic components of the mammalian stress response. Within the endocrine hypothalamic-pituitary-adrenal axis, this 41-amino acid peptide is the key mediator of ACTH secretion. Hypothalamic CRH is released in response to stressful stimuli and carried to the anterior pituitary where it activates $\mathrm{CRH}$ receptors on anterior pituitary corticotropes, resulting in increased ACTH synthesis and secretion. ACTH acts on the adrenal cortex to increase glucocorticoid release; glucocorticoids then mediate many of the metabolic changes required to respond to the stressor. $\mathrm{CRH}$ is also expressed in many other sites in the central nervous system (CNS) where it is thought to act as a neurotransmitter to mediate changes in a wide variety of stress-associated behaviors. For example, CRH has been implicated in stress-induced alterations in anxiety-like behavior, feeding behavior, and locomotor activity (Dunn \& Berridge 1990, Owens \& Nemeroff 1991).

$\mathrm{CRH}$ has also been shown to play an important role in stress-induced inhibition of reproductive function. The i.c.v. injection of CRH suppresses the activity of the hypothalamic-pituitary-gonadal (HPG) axis in rats, resulting in decreased release of GNRH1 and LH (LHB; reviewed in Rivest \& Rivier (1995)). Similarly, the repression of pulsatile LHB secretion by restraint stress, lipopolysaccharide, insulininduced hypoglycemia, or fasting can be reversed by the icv injection of CRH receptor antagonists (Maeda et al. 1994, Li et al. 2005, 2006), suggesting that CRH receptor ligands mediate inhibitory effects of stress on the HPG axis via central pathways (reviewed in Rivest \& Rivier (1995)). While studies suggest that systemic administration of $\mathrm{CRH}$ does not alter LHB secretion in rats (Rivier \& Vale 1984), CRH treatment of primary rat pituitary cultures decreased basal LHB secretion (Blank et al. 1986). Numerous other hypothalamic peptides have also been shown to modulate gonadotropin levels by acting at the pituitary (reviewed in Evans (1999)). Thus, CRH and other members of the CRH family of peptides, urocortin (UCN), urocortin 2 (UCN2), and urocortin 3 (UCN3), may participate in the stress-mediated regulation of reproduction via multiple mechanisms and sites of action. 
$\mathrm{CRH}$ and the urocortins mediate their effects via two distinct CRH receptors: CRHR1 and CRHR2 (reviewed in Dautzenberg \& Hauger (2002), Grammatopoulos \& Chrousos (2002), Bale \& Vale (2004) and Hillhouse \& Grammatopoulos (2006)). The receptors are $\sim 70 \%$ identical at the amino acid level and are both members of the class B subfamily of seven transmembrane domain G-proteincoupled receptors. In most cell types, the activation of CRHR 1 or CRHR 2 by CRH or urocortins results in the activation of the Gs-adenylyl cyclase pathway and increased cAMP levels; however, recent evidence has demonstrated that in some tissues and cell types both CRH receptors can couple to other G-proteins including $\mathrm{Gq}, \mathrm{Gi}$, and Go, resulting in the activation of various kinases including PKC, MAPK, and Akt1 (reviewed in Grammatopoulos \& Chrousos (2002) and Hillhouse \& Grammatopoulos (2006)). CRHR1 and CRHR2 differ in their pharmacological properties (reviewed in Dautzenberg \& Hauger (2002), Grammatopoulos \& Chrousos (2002), Bale \& Vale (2004) and Hillhouse \& Grammatopoulos (2006)). CRHR1 has very high affinity for both CRH and UCN (Vaughan et al. 1995). By contrast, CRHR2 has a significantly higher affinity (20- to 40-fold) for UCN than for CRH (Vaughan et al. 1995); UCN2 and UCN3 are relatively selective for CRHR2, and have been suggested to be CRHR2-specific ligands (Hsu \& Hsueh 2001, Lewis et al. 2001, Reyes et al. 2001).

CRHR1 has been detected in numerous sites in the brain (i.e., cerebellum, cerebral cortex, amygdala, various limbic, and sensory nuclei), the intermediate lobe of the pituitary, and a subset of corticotropes in the anterior lobe of the rat pituitary (Potter et al. 1994, Van Pett et al. 2000). Recent studies from our laboratory have demonstrated Crhr $1 \mathrm{mRNA}$ not only in a subset of corticotropes but also in a subset of lactotropes and gonadotropes in murine anterior pituitary (Westphal et al. 2009). CRHR2 has been isolated in two alternatively spliced forms in the rodent (CRHR2 $\alpha$ and CRHR2 $\beta$ which utilize alternative amino termini) and exhibits an mRNA expression profile that is distinct from that of CRHR1 (Chalmers et al. 1995, Lovenberg et al. 1995b). CRHR $2 \alpha$ is expressed primarily in brain (Chalmers et al. 1995, Lovenberg et al. 1995a), while CRHR2 $\beta$ is found largely in the periphery, but is also detected in the choroid plexus and cerebral arterioles (Chalmers et al. 1995, Lovenberg et al. 1995a). Within the pituitary, CRHR2 is expressed predominantly in the posterior lobe; however, a very low but detectable level of Crhr 2 mRNA is also detected in the anterior lobe by in situ hybridization (Van Pett et al. 2000, Kageyama et al. 2003). Consistent with the potential expression of CRHR2 in anterior pituitary, Kageyama and colleagues recently demonstrated CRHR $2 \alpha$ mRNA in rat anterior pituitary and Crhr 2 mRNA in rat gonadotropes (Kageyama et al. 2003). These results suggest that both CRHR 1 and CRHR2 may bind CRH and urocortins not only in the CNS but also in the pituitary to modulate stressrelated functions.
To investigate the potential action of CRH specifically on pituitary gonadotrope function, we examined the $\mathrm{CRH}$ receptor expression and functional signaling in $\alpha \mathrm{T} 3-1$ cells, a murine gonadotrope precursor cell line. These cells were originally derived by targeted oncogenesis in transgenic mice (Windle et al. 1990) and they express GNRH1 receptors and the $\alpha$-subunit of the glycoprotein hormone, but not LHB or FSHB. They exhibit a number of characteristics equivalent to gonadotropes in primary pituitary cultures, demonstrating the utility of these cells as a model system for the study of gonadotrope function (Horn et al. 1991).

\section{Materials and Methods}

\section{Cell culture}

aT3-1 cells were kindly provided by Dr Pamela Mellon (University of California, San Diego; Windle et al. 1990). They were maintained in DMEM (Life Technologies) plus $10 \%$ FCS (Hyclone, Logan, UT, USA) at $37^{\circ} \mathrm{C}$ in $5 \% \mathrm{CO}_{2}$.

\section{cAMP assays}

aT3-1 cells were plated (300 000 cells/well) onto 6-well plates (Falcon 3046) and used 2-3 days after plating. The cells were washed two times with DMEM and preincubated for 45-60 min in DMEM containing $1 \mathrm{mM}$ isobutylmethylxanthine (IBMX; Sigma) to inhibit cAMP phosphodiesterase activity. Preincubation media were removed and DMEM $(1 \mathrm{ml})$ containing $1 \mathrm{mM}$ IBMX and various concentrations of human/rat CRH, rat UCN, mouse UCN2, mouse UCN3, $\boldsymbol{\alpha}$-helical CRH (9-41), astressin (AST; American Peptide Company, Sunnyvale, CA, USA), or antisauvagine (Bachem, Torrance, CA, USA) were added. The cells were incubated at room temperature for the indicated lengths of time before the removal of stimulation media. Then the cells were immediately lysed and intracellular cAMP levels were determined. The cyclic AMP $\left({ }^{3} \mathrm{H}\right)$ assay system (Amersham Biosciences) was used for the time-course, dose-response profiles with CRH and UCN, and $\alpha$-helical CRH 9-41 and AST antagonist studies. In this assay, the cells were lysed and incubated for $16-24 \mathrm{~h}$ at $-20{ }^{\circ} \mathrm{C}$ with $95 \%$ ethanol $/ 20 \mathrm{mM}$ $\mathrm{HCl}(1 \mathrm{ml} /$ well). Cell lysates were then dried under vacuum, resuspended in $300 \mu \mathrm{l}$ of $0.05 \mathrm{M}$ Tris ( $\mathrm{pH} 7 \cdot 5$ ), $4 \mathrm{mM}$ EDTA, and cAMP levels were determined in $50 \mu \mathrm{l}$ samples, according to the manufacturer's protocol, using triplicate wells and duplicate assays for each time point or treatment value. Additional dose-response studies with UCN, UCN2, and UCN3 and antisauvagine antagonist studies were performed with the direct cAMP enzyme Immunoassay kit (catalog no. 901-066; Assay Designs Inc., Ann Arbor, MI, USA). After the removal of the stimulation media, the cells were lysed by 20 -minute incubation in $1 \mathrm{ml}$ of $0 \cdot 1 \mathrm{M} \mathrm{HCl}$. The cell lysates were centrifuged at $600 \mathrm{~g}$ at room temperature for $5 \mathrm{~min}$ and the supernatants were used directly in the assay $(50 \mu \mathrm{l} /$ well $)$ or stored at $-20{ }^{\circ} \mathrm{C}$. 
As above, duplicate assays and duplicate or triplicate wells were used for each treatment condition. Each experiment was performed at least two times; dose profiles were repeated three to five times.

\section{$R N A$ isolation and $c D N A$ synthesis}

Total RNA was isolated from mouse brain, hypothalamus, heart, and $\alpha \mathrm{T} 3-1$ cells using TRIzol reagent (Invitrogen). Five micrograms of RNA were used for random hexamer-primed first-strand cDNA synthesis (Novagen Inc, Madison, WI, USA). To control for genomic DNA contamination, cDNA synthesis was performed in the presence and absence of SuperScript II Reverse Transcriptase (Life Technologies, Inc.) for each of the RNA samples. The products of cDNA synthesis were purified using QIAquick PCR Purification kit (Qiagen Inc).

\section{RT-PCRs}

RT-PCR was performed in a final volume of 25 or $50 \mu \mathrm{l}$ using 1-3 $\mu \mathrm{l}$ cDNA product, $200 \mu \mathrm{M}$ deoxyribonucleotides, $1.0 \mu \mathrm{M}$ primers, Taq buffer with $\mathrm{MgCl}_{2}$, and $1-25 \mathrm{U}$ Taq DNA polymerase or platinum Taq DNA polymerase (Invitrogen Inc). Cycle conditions are described below. Based on the mouse CRHR1 genomic structure (Ensembl ENSMUST00000093925), the primers for mouse CRHR1 were designed to span at least one intron in the genomic sequence. The primer pair for CRHR1 (Fig. 1A) was as follows: forward primer, 5'-GGA-TCA-GCA-GTG-TGA-GAGCCT-3' ${ }^{\prime}$ and reverse primer, $5^{\prime}$-GTT-CCA-GTG-GAT-GATGTT-CCT-3' (amplifying a 394 bp fragment from nucleotides 109 to 502 of mouse Crhr 1 cDNA, GenBank accession no. X72305). PCR amplification conditions were 34 cycles of $94^{\circ} \mathrm{C}$ for $30 \mathrm{~s}, 69^{\circ} \mathrm{C}$ for $30 \mathrm{~s}$, and $72{ }^{\circ} \mathrm{C}$ for $30 \mathrm{~s}$.

The genomic organization and the sequence of mouse CRHR 2 was recently published (Chen et al. 2005). Exons 1 and 2 are spliced to exon 4 to produce CRHR $2 \beta$ while exon 3 is spliced to exon 4 to produce CRHR $2 \alpha$. Our primers for PCR were designed to span at least one intron. For CRHR $2 \alpha$, the forward primer was $5^{\prime}$-CTC-CTC-AGCCTG-CTG-GAG-GCC-AAC-T- ${ }^{\prime}{ }^{\prime}$ and the reverse primer was 5'-GTT-CTC-CAG-GCA-CTC-TCT-GTA-GGCATT-3' (exons 3-5, amplifying a $243 \mathrm{bp}$ fragment from nucleotides 158 to 400 of mouse CRHR $2 \alpha$ cDNA, GenBank accession no. AY445512). For CRHR2 $\beta$, the forward primer was $5^{\prime}$-GGC-CTA-AGA-GAG-AGGCCG-GAC-AGA-CCT-CCT-TTG-GA-3' ${ }^{\prime}$ and the reverse primer was $5^{\prime}$-AGA-ATG-AAG-GTG-GTG-ATG-AGGTTC-CAG-TGG-ATC-ACA-3' (exons 1-7, amplifying a $631 \mathrm{bp}$ fragment from nucleotides 40 to 670 of mouse CRHR2 $\beta$ cDNA, GenBank accession no. NM_009953). Both PCR amplifications included 30 cycles of $92^{\circ} \mathrm{C}$ for $60 \mathrm{~s}$, $66^{\circ} \mathrm{C}$ for $90 \mathrm{~s}$, and $72{ }^{\circ} \mathrm{C}$ for $90 \mathrm{~s}$.

All PCR products were electrophoresed and visualized on an ethidium bromide-stained $1.0 \%$ agarose gel. The $1 \mathrm{~kb}$ plus
DNA ladder (Fig. 1A) or 1 kb DNA ladder (Fig. 1B and C; Invitrogen) was used for DNA size standards.

\section{Transient transfections and reporter constructs}

Cultures of $\alpha$ T3-1 cells were plated onto 6-well plates (400 000 cells/well) in DMEM + 10\% FCS + gentamicin $(50 \mu \mathrm{g} / \mathrm{ml})$. The cells were transfected $12-24 \mathrm{~h}$ later, using FuGENE (see the manufacturer's recommendations; Roche) with $1.75 \mu \mathrm{g}$ luciferase reporter DNA and $0.25 \mu \mathrm{g}$ RSV- $\beta$ gal DNA per well. The $\alpha$-subunit-luciferase construct was kindly provided by Dr Sally Camper (University of Michigan) and contains $480 \mathrm{bp}$ of the mouse glycoprotein hormone $\alpha$-subunit promoter $(-480$ to $+43 \mathrm{bp})$ fused to the luciferase reporter gene (Brinkmeier et al. 1998). RSV- $\beta$ gal was used to normalize for transfection efficiency. For all studies, $10 \mu \mathrm{M}$ forskolin (Calbiochem, San Diego, CA, USA) or various concentrations of UCN peptides were applied at $40 \mathrm{~h}$ post-transfection. The cells were harvested $4 \mathrm{~h}$ later (44 $\mathrm{h}$ post-transfection) in cold $1 \times \mathrm{PBS}$, pelleted, and lysed in $100 \mu \mathrm{l}$ lysis buffer $(0 \cdot 25 \mathrm{M}$ Tris $(\mathrm{pH} 8 \cdot 0), 0 \cdot 1 \mathrm{M}$ EDTA, $15 \mathrm{mM} \mathrm{MgSO}_{4}, 1 \mathrm{mM}$ DTT, and $1 \%$ Triton X-100) and incubated on ice for $10 \mathrm{~min}$. Lysates were centrifuged at 10000 r.p.m. for $10 \mathrm{~min}$ at $4{ }^{\circ} \mathrm{C}$ and $5 \mu$ of each supernatant were added to $100 \mu$ lof luciferase assay buffer (Cortright et al. 1997) and assayed for $30 \mathrm{~s}$ in a Turner 20/20 luminometer; $\beta$-galactosidase activity was assayed as described previously. Data are represented as fold induction over untreated vehicle control (untreated controls $=1 \cdot 0$ ). Experiments were performed in duplicate and each experiment was repeated at least three independent times. Fold inductions from three independent experiments were combined for the $\alpha$-luciferase transfection data presented.

\section{Data analysis and statistical methods}

All data are presented as mean \pm s.E.M. Statistical significance of the cAMP responses over time and in the presence of $\mathrm{CRH}$ receptor antagonists was determined by ANOVA with post hoc analysis using StatView (Abacus Concepts). Duplicate or triplicate wells were used for all cAMP assays and at least two to five independent assays were performed for each study. The EC50 values for $\mathrm{CRH}, \mathrm{UCN}, \mathrm{UCN} 2$, and UCN3 were determined by non-linear regression analyses using GraphPad Prism (version 3.0) software (GraphPad). Statistical analysis for the transient transfection studies was performed using a one-way ANOVA followed by multiple comparison post hoc analysis, where all selected groups were analyzed simultaneously. Analysis was performed using StatView and $\mathrm{p}$ values that reached $95 \%$ confidence levels are included in each figure legend.

\section{Results}

Expression of CRH receptor $m R N A$ in $\alpha$ T3-1 cells

RT-PCR was utilized to characterize the expression of $\mathrm{Crhr} 1$ and Crhr2 mRNA in $\alpha \mathrm{T} 3-1$ cells. cDNA synthesis reactions 
A

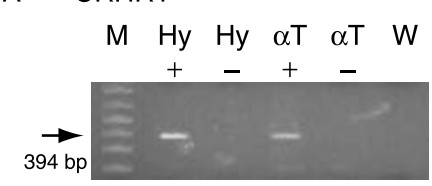

B

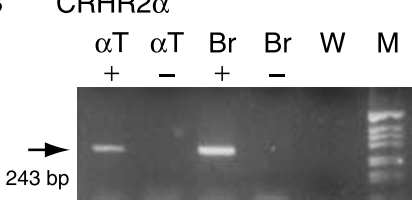

C

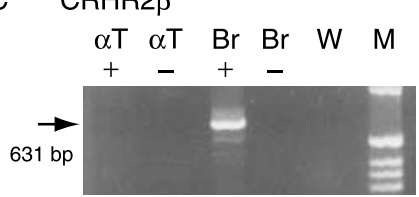

Figure 1 Expression of CRHR1 and CRHR2 $\alpha$ RNA in $\alpha \mathrm{T} 3-1$ cells. RT-PCR was utilized to test for the expression of CRH receptor RNA in $\alpha \mathrm{T} 3-1$ cells. (A) Utilizes primers specific for CRHR1 and (B) and (C) utilize primers specific for CRHR2 $\alpha$ and CRHR2 $\beta$ respectively. The presence or absence of reverse transcriptase (RT) during CDNA synthesis is indicated by + or - signs. (A) An amplified product of 394 bp in hypothalamus and $\alpha$ T3-1 cDNA lanes (see arrow). $\mathrm{Hy}+$ (hypothalamus, with RT), $\mathrm{Hy}-$ (hypothalamus, without RT), $\alpha \mathrm{T}+$ ( $\alpha \mathrm{T} 3-1$, with RT), $\alpha \mathrm{T}-(\alpha \mathrm{T} 3-1$, without RT), W (water control). (B) An amplified product of 243 bp in $\alpha \mathrm{T} 3-1(\alpha \mathrm{T}+)$ and brain $(\mathrm{Br}+)$ cDNA lanes (see arrow). These bands are consistent with the expression of CRHR2 $\alpha$ in $\alpha \mathrm{T} 3-1$ and total brain RNA samples. (C) Amplified products of $631 \mathrm{bp}$ only in the brain $(\mathrm{Br}+$ ) lane (see arrow). The absence of amplified product in the $\alpha \mathrm{T}+$ lane indicates that CRHR2 $\beta$ is not detectable in $\alpha \mathrm{T} 3-1$ RNA. M represents $1 \mathrm{~kb}$ plus (Invitrogen) DNA ladder in (A) and $1 \mathrm{~kb}$ (Invitrogen) DNA ladder in (B) and (C).

were performed in the presence $(+)$ and absence $(-)$ of reverse transcriptase to provide controls for genomic DNA contamination of the cDNA. CRHR1 and CRHR2 PCR primer pairs were also specifically designed to span at least one intron. Mouse hypothalamus (Hy) and mouse total brain (Br) cDNA were used as positive controls for CRHR1 and CRHR2 respectively. As shown in Fig. 1A, the primer pair for CRHR1 demonstrates the presence of an appropriately sized PCR fragment in the cDNA from $\alpha \mathrm{T} 3-1$ cells $(\alpha \mathrm{T}+)$ and mouse hypothalamus $(\mathrm{Hy}+)$ (394 bp, Fig. 1A). No bands were seen in the minus reverse transcriptase lanes $(-)$, suggesting the absence of genomic DNA contamination. RT-PCR with two additional primer pairs confirmed the presence of CRHR1 in $\alpha$ T3-1 cells (data not shown; Westphal et al. 2009).

RT-PCR was also performed using multiple sets of primer pairs for CRHR2. CRHR 2 is expressed in two alternatively spliced forms in the rodent: CRHR $2 \alpha$ and CRHR $2 \beta$ $(14,19)$. These alternatively spliced transcripts differ in the $5^{\prime}$-untranslated region and the $\mathrm{NH}_{2}$ terminus of the encoded protein. Primer pairs were selected that contained the $5^{\prime}$-forward primer within the alternatively spliced region of the transcript, providing specificity for the CRHR $2 \alpha$ or CRHR $2 \beta$ mRNAs. The results shown in Fig. 1B demonstrate the presence of an appropriately sized fragment for CRHR $2 \alpha$ (243 bp) in $\alpha \mathrm{T} 3-1(\alpha \mathrm{T}+)$ and mouse total brain $(\mathrm{Br}+)$ cDNA. The $243 \mathrm{bp}$ fragment from $\alpha \mathrm{T} 3-1$ cDNA was subcloned; DNA sequence analysis confirmed that the fragment contained the CRHR $2 \alpha$ cDNA sequence. Additional primer pairs also confirmed the presence of CRHR $2 \alpha$ in $\alpha$ T3-1 cells (data not shown). The cDNA samples used for the PCR in Fig. 1B were also tested with several different CRHR $2 \beta$ primer pairs. While the $631 \mathrm{bp}$ CRHR2 $\beta$-specific PCR product is readily detected in total brain $(\mathrm{Br}+)$ (Fig. 1C) or mouse heart (not shown), CRHR $2 \beta$ is not detected in the same $\alpha \mathrm{T} 3-1$ cDNA samples $(\alpha \mathrm{T}+)$ that readily detected CRHR $2 \alpha$. Additional primer pairs also failed to demonstrate detectable levels of CRHR $2 \beta$ in the $\alpha \mathrm{T} 3-1$ samples. Together, the data in Fig. 1A-C clearly demonstrate the presence of Crhr1 and CRHR $2 \alpha$ mRNAs in $\alpha$ T3-1 cells, with non-detectable levels of CRHR $2 \beta$ transcripts.

\section{Stimulation of cAMP production in $\alpha$ T3-1 cells by $C R H$ and $U C N$}

CRH receptors have been shown to couple to Gs in many tissues and cell lines, resulting in increased intracellular cAMP levels. To test the intracellular signaling of the $\mathrm{CRH}$ receptors in $\alpha \mathrm{T} 3-1$ cells, the cells were treated with $200 \mathrm{nM}$ CRH or $\mathrm{UCN}$ in the presence of $1 \mathrm{mM}$ IBMX for various lengths of time and cAMP production was examined. UCN and CRH bind to both CRHR1 and CRHR2, although CRH binds to CRHR 2 with a 14 -fold lower affinity than CRHR $1\left(K_{\mathrm{i}}=13\right.$ and $0.95 \mathrm{nM}$ respectively), while UCN binds to both CRHR1 and CRHR2 with very high affinity $\left(K_{\mathrm{i}}<\right.$ 1.0 nM; Donaldson et al. 1996). As shown in Fig. 2, treatment of $\alpha$ T3-1 cells with CRH or UCN resulted in rapid increases in the intracellular cAMP levels. The CRH- and UCNmediated increases in cAMP were maximal at $2-5 \mathrm{~min}$ and were significantly increased over the levels in vehicle-treated cells (dashed line). The increased cAMP levels were usually two- to fourfold over basal levels, and maximal levels of cAMP did not significantly differ between $\mathrm{CRH}$ and UCN treatments within the experiments. Interestingly, the intracellular cAMP levels decreased rapidly from peak values even in the presence of $1 \mathrm{mM}$ IBMX.

\section{Dose-dependent stimulation of cAMP production in $\alpha$ T3-1 cells} by $C R H$ and $U C N$

Dose-response studies were performed using various concentrations of CRH or UCN in the presence of $1 \mathrm{mM}$ IBMX. As time-course experiments had shown maximal 


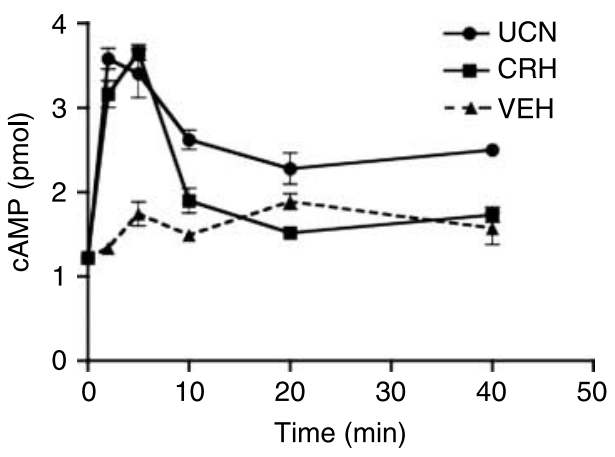

Figure 2 Time-dependent increases in intracellular cAMP levels in aT3-1 cells after treatment with $\mathrm{CRH}$ or UCN. The cells were treated with $200 \mathrm{nMCRH}$ or UCN for 2, 5, 10, 20, and $40 \mathrm{~min}$ in the presence of $1 \mathrm{mM}$ IBMX. cAMP assays were performed on cell lysates. The addition of $\mathrm{CRH}(\square)$ or $\mathrm{UCN}(\mathrm{O})$ resulted in a rapid increase in intracellular cAMP levels when compared with vehicle treatment (dashed line). Points represent the average ( \pm s.E.M.) for triplicate wells from a representative experiment.

intracellular cAMP levels at $2-5 \mathrm{~min}$ after the addition of ligand, all treatments were for $3 \mathrm{~min}$. As shown in Fig. 3, cAMP levels increased in $\alpha \mathrm{T} 3-1$ cells in a dose-dependent fashion in response to $\mathrm{CRH}$ or UCN treatment. $\mathrm{CRH}$ and UCN were similar in potency and showed equivalent maximum cAMP levels across multiple experiments. The half-maximal stimulatory (EC50) concentrations of CRH and UCN were not significantly different with the values of $14 \cdot 5 \mathrm{nM} \pm 5 \cdot 9(n=3)$ and $21 \cdot 2 \mathrm{nM} \pm 5 \cdot 1(n=7)$ respectively.

Inhibition of $C R H$ - and UCN-mediated increases in $C A M P$ with non-selective CRH receptor antagonists

We used CRH receptor antagonists ( $\alpha$-helical CRH 9-41 and AST) that block both CRHR1 and CRHR2 (reviewed in Hauger et al. (2006)) to determine whether the CRH- and

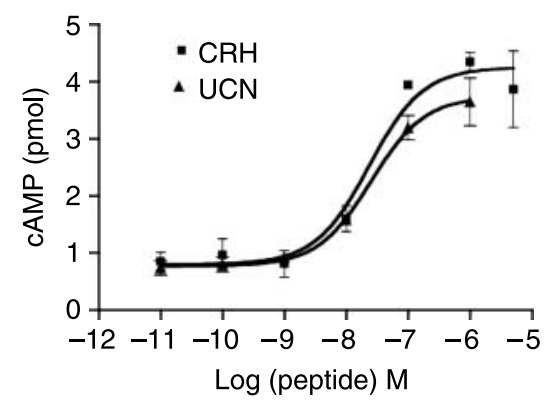

Figure 3 Dose-dependent increases in cAMP levels in $\alpha \mathrm{T} 3-1$ cells following treatment by $\mathrm{CRH}(\square)$ or $\operatorname{UCN}(\triangle)$. Intracellular levels of cAMP are shown after the treatment of $\alpha \mathrm{T} 3-1$ cells with various concentrations of $\mathrm{CRH}$ or UCN. Treatments were for $3 \mathrm{~min}$. Points are the average ( \pm S.E.M.) from duplicate assays on triplicate wells from a representative experiment. The maximal cAMP levels are not significantly different following $\mathrm{CRH}$ or $\mathrm{UCN}$ treatment and the EC50 values are also not significantly different.
UCN-mediated increases in intracellular cAMP were specifically mediated by CRH receptors. The cells were pretreated for $1 \mathrm{~h}$ with $1 \mathrm{mM}$ IBMX and fresh media were added that contained $100 \mathrm{nM} \mathrm{CRH}$ or UCN in the presence or absence of $10 \mu \mathrm{M} \alpha$-helical CRH 9-41 (9-41, Fig. 4A) or $1 \mu \mathrm{M}$ AST (Fig. 4B). Cells were also treated with vehicle or receptor antagonist alone. All treatments were for $3 \mathrm{~min}$. $\alpha$-Helical CRH 9-41 treatment alone showed a small but significant increase in the intracellular cAMP levels (Fig. 4A). CRH or UCN treatment alone also resulted in a significant increase in cAMP, while co-administration with $\boldsymbol{\alpha}$-helical CRH 9-41 reduced cAMP values to vehicle-treated levels. The $\alpha$-helical CRH 9-41 results shown here are consistent with the previous studies that suggest that it is not a pure antagonist, demonstrating
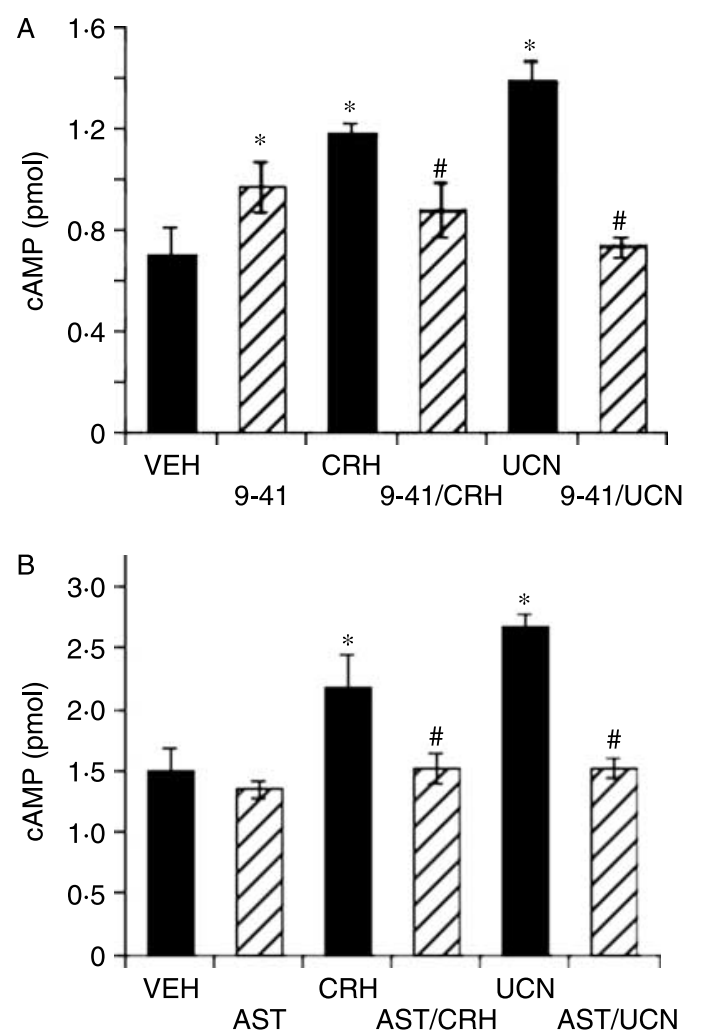

Figure 4 Inhibition of $\mathrm{CRH}$ - or UCN-mediated stimulation of CAMP levels by CRH receptor antagonists $\alpha$-helical CRH 9-41 or astressin. (A) $\alpha \mathrm{T} 3-1$ cells were treated with DMEM/IBMX containing vehicle, $10 \mu \mathrm{M} \alpha$-helical CRH 9-41 (9-41), $100 \mathrm{nM} \mathrm{CRH,} 100 \mathrm{nM} \mathrm{UCN}$, or 9-41 plus CRH or UCN for 3 min. Intracellular CAMP levels after 9-41, CRH, or UCN treatments were significantly increased from vehicle-treated levels $\left(\mathrm{VEH}\right.$; ${ }^{*}$ significance from $\left.\mathrm{VEH}, P<0 \cdot 05\right)$. In addition, treatments with 9-41 in the presence of CRH or UCN blocked the $\mathrm{CRH}$ - and UCN-mediated increases in intracellular CAMP (" significantly different from CRH or UCN treatments alone, $P<0 \cdot 05)$. (B) $\alpha \mathrm{T} 3-1$ cells were treated as above except that astressin (AST, $1 \mu \mathrm{M}$ ) was used alone or in combination with $100 \mathrm{nM} \mathrm{CRH}$ or UCN. These results also show significant inductions in CAMP levels with $\mathrm{CRH}$ and $\mathrm{UCN}$ and significant repressions of $\mathrm{CRH}$ - or $\mathrm{UCN}$-mediated increases in CAMP by the addition of astressin. ${ }^{*}$ and ${ }^{\#}$ are used as in (A). 
weak intrinsic agonist activity (Baldwin et al. 1991, Hauger et al. 2006). A second non-selective CRH receptor antagonist, AST (Fig. 4B), also showed complete suppression of the CRH- and UCN-mediated increases in cAMP, with no significant effect of AST alone. Together, these studies clearly demonstrate that CRH and UCN mediate significant increases in the intracellular cAMP levels that can be effectively inhibited by the $\mathrm{CRH}$ receptor antagonists that block both CRHR1 and CRHR2 signaling.

\section{Contributions of CRHR2 to the cAMP signaling in $\alpha T 3-1$ cells}

To determine the contribution of CRHR2 to the overall cAMP increases in $\alpha \mathrm{T} 3-1$ cells in response to CRH ligands, we stimulated the cells with various doses of UCN2 and UCN3, CRHR2-specific ligands (Jahn et al. 2004). The EC50 values for cAMP stimulation for UCN2 and UCN3 were $20.3 \mathrm{nM} \pm 9 \cdot 7(n=3)$ and $32.5 \mathrm{nM} \pm 8 \cdot 2(n=3)$, not significantly different from each other or the EC50 value of UCN $(21 \cdot 2 \pm 5 \cdot 2 \mathrm{nM}, n=7)$. At maximal doses of UCN2 and UCN3 $(100 \mathrm{nM})$, we observed increases in cAMP levels that reached $60 \cdot 0 \pm 7 \cdot 6 \%(n=6)$ and $54 \cdot 3 \pm 6 \cdot 0 \%$ $(n=13)$ of the levels obtained with UCN or CRH $(90.9 \pm$ $11 \cdot 0 \%$ relative to $\mathrm{UCN}$; Fig. $5 \mathrm{~A}$ ), demonstrating that both CRHR 1 and CRHR 2 can contribute to the cAMP increases in $\alpha \mathrm{T} 3-1$ cells.

To further confirm the contribution of CRHR2 to the UCN-mediated increases in cAMP, we utilized a selective CRHR2 antagonist, antisauvagine (Ruhmann et al. 1998, Brauns et al. 2002). This peptide has a 100- to 400-fold greater selectivity for CRHR2 than CRHR1. The cells were pretreated with antisauvagine for $15 \mathrm{~min}$ before the addition of UCN or the CRHR2-specific agonist, UCN 3. As shown in Fig. 5B, the cAMP levels after antisauvagine treatment alone did not significantly differ from the vehicle. However, antisauvagine completely blocked the UCN3-mediated increase in cAMP, while only partially blocking $(75 \%$ repression) the UCN-mediated cAMP increases, consistent with both CRHR 1 and CRHR 2 contributing to the UCNmediated cAMP increases.

\section{UCN increases $\alpha$-luciferase transcriptional activity}

While LHB and FSHB are not produced in $\alpha \mathrm{T} 3-1$ cells, the glycoprotein hormone $\alpha$-subunit is actively transcribed and translated in these cells and its expression is highly regulated by GNRH1, gonadal steroids, and a variety of peptides including pituitary adenylyl cyclase activating polypeptide (PACAP) and endothelin 1, working through numerous intracellular signaling pathways (reviewed in McArdle \& Counis (1996) and Evans (1999)). PACAP has been shown to increase the intracellular cAMP levels in $\alpha \mathrm{T} 3-1$ cells, resulting in increased transcriptional activity and steady-state levels of $\alpha$-subunit mRNA (Schomerus et al. 1994, Tsujii et al. 1995, Attardi \& Winters 1998, Burrin et al. 1998). As the cAMP levels are also rapidly increased by CRH or UCN
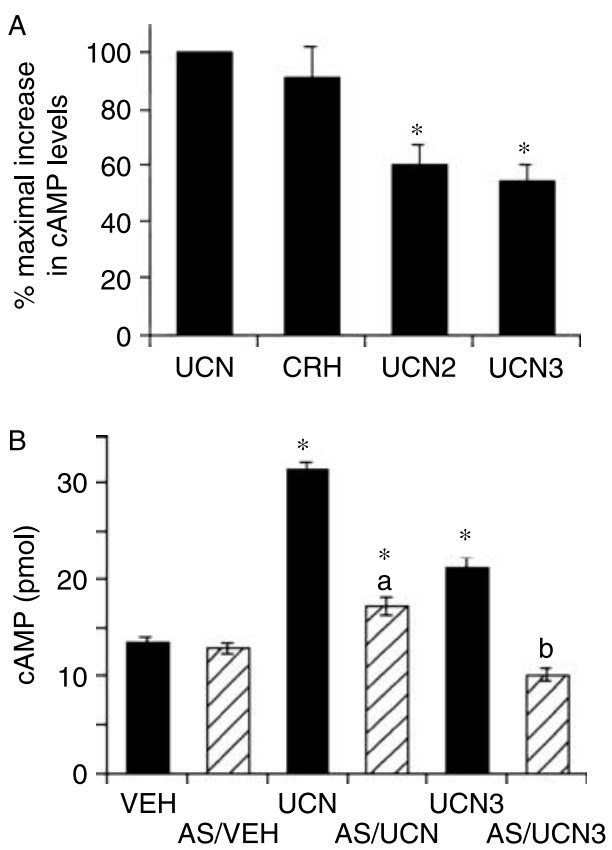

Figure 5 Functional role of CRHR2 in CAMP signaling in $\alpha \mathrm{T} 3-1$ cells. (A) $\alpha \mathrm{T} 3-1$ cells were treated with vehicle, CRH, UCN, UCN2, or UCN3 (100 nM) for $3 \mathrm{~min}$. Intracellular cAMP levels were determined and the increase in CAMP levels under each treatment condition (from VEH) was normalized to that observed with UCN (set to $100 \%$ ). UCN2 and UCN3 showed significantly lower elevations in cAMP, showing only $50-60 \%$ of the increases obtained with UCN or CRH (*significantly different from UCN, $P<0 \cdot 05$ ), suggesting that CRHR2 contributes $\sim 50 \%$ to the CAMP increases observed after stimulation with UCN. (B) $\alpha$ T3-1 cells were pretreated with antisauvagine (AS, $1 \mu \mathrm{M}$ ) or vehicle for $15 \mathrm{~min}$ followed by a 3-minute treatment with UCN or UCN3 (100 nM) in the presence or absence or antisauvagine. Intracellular cAMP levels after UCN treatments were significantly increased from vehicletreated levels (VEH; *significantly different from VEH, $P<0 \cdot 05)$, with UCN-mediated increases being significantly greater than UCN3-mediated increases. There was no significant difference in the intracellular CAMP levels between VEH and AS treatments. Treatment with AS in the presence of UCN3 completely blocked the UCN3-mediated increases ( ${ }^{b}$ significantly different from UCN3, $P<0 \cdot 05)$, resulting in CAMP levels not significantly different from VEH or AS. Treatment with AS in the presence of UCN significantly reduced cAMP levels from $U C N$ ( ${ }^{a}$ significantly different from $U C N$, $P<0 \cdot 05)$, but cAMP levels remained significantly greater than $\mathrm{VEH}$, AS/VEH, or AS/UCN3 levels, suggesting that activated CRHR1 was responsible for the remaining CAMP increase.

in these cells, we utilized a mouse $\boldsymbol{\alpha}$-subunit promoterluciferase reporter construct ( $\boldsymbol{\alpha}$-luciferase) in transfection studies to assess the increased transcriptional activity of the $\boldsymbol{\alpha}$-subunit promoter in $\alpha \mathrm{T} 3-1$ cells after treatment with UCN. As shown in Fig. 6, UCN significantly increased $\boldsymbol{\alpha}$-luciferase activity in a dose-dependent manner from 30 to $300 \mathrm{nM}$, reaching levels that were not significantly different from those induced by forskolin, a direct activator of adenylyl cyclase. As the mouse $\boldsymbol{\alpha}$-subunit promoter is known to contain cAMP response elements and has previously been shown to be activated by increased cAMP/PKA activation 


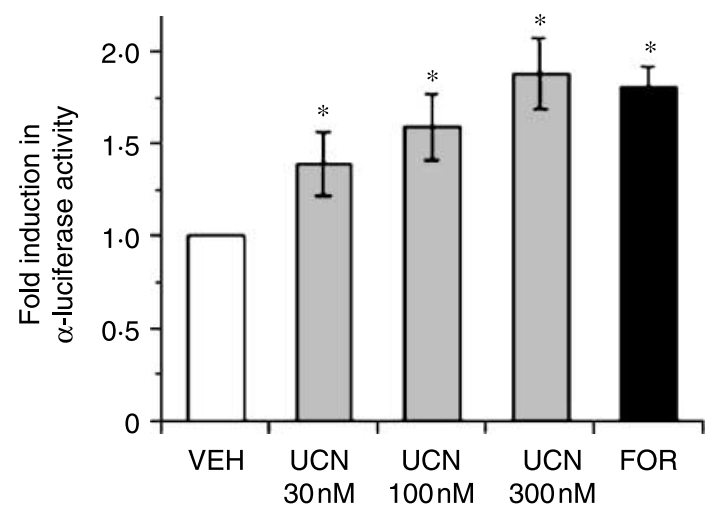

Figure 6 Dose-dependent increases in $\boldsymbol{\alpha}$-luciferase activity in transiently transfected $\alpha \mathrm{T} 3-1$ cells following treatment with UCN. Treatment of $\alpha$-luciferase-transfected $\alpha \mathrm{T} 3-1$ cells with UCN (30 nM, $100 \mathrm{nM}$, or $300 \mathrm{nM}, 4 \mathrm{~h})$ or forskolin $(10 \mu \mathrm{M}, 4 \mathrm{~h})$ significantly induced $\alpha$-luciferase promoter activity. The relative promoter activity is represented as fold induction over control. Values represent the mean \pm S.E.M. $(n=3) .{ }^{*} P<0 \cdot 05$, when compared with vehicle control.

(Schoderbek et al. 1992, Attardi \& Winters 1998), these results are consistent with the $\mathrm{CRH}$-mediated elevations in cAMP causing an increase in $\alpha$-subunit promoter-directed transcriptional activity in $\alpha \mathrm{T} 3-1$ cells.

\section{Discussion}

We have demonstrated via RT-PCR that CRHR1 and CRHR $2 \alpha$ mRNAs are expressed in $\alpha \mathrm{T} 3-1$ cells. These G-protein-coupled receptors are functional and couple through Gs, as treatment of these cells with CRH or UCN results in significant increases in intracellular cAMP levels that can be blocked completely by the presence of non-selective $\mathrm{CRH}$ receptor antagonists. Our results also demonstrate that both CRHR 1 and CRHR $2 \alpha$ are functional in these cells as CRHR2-specific ligands increase cAMP levels to only $50-60 \%$ of the levels observed with non-selective agonists (CRH and UCN), and CRHR2-selective antagonists do not completely abolish the UCN-mediated increases in cAMP. In addition, we have shown that UCN treatment of $\alpha$ T3-1 cells results in increased transcriptional activity of the glycoprotein hormone $\boldsymbol{\alpha}$-subunit promoter, a promoter known to be positively regulated by elevated cAMP levels. These results are the first to demonstrate both the expression and functional signaling of CRHR 1 and CRHR $2 \alpha$ in murine gonadotropelike cells, and they suggest a potential direct role for $\mathrm{CRH}$ or the other CRH-like ligands, UCN, UCN2, and UCN3, in the modulation of gonadotropin transcription and secretion at the level of the anterior pituitary gonadotrope. This proposed regulation at the pituitary could complement or modulate the $\mathrm{CRH}$-mediated regulation of hypothalamic GNRH1 production and secretion.
In the rodent, Crhr 1 mRNA has been localized primarily in the brain and intermediate and anterior lobes of the pituitary (Potter et al. 1994, Van Pett et al. 2000). While Crhr 1 mRNA had previously been detected in a subset of rat corticotropes (Potter et al. 1994), recent studies from our laboratory have also demonstrated Crhr1 mRNA in a subset of cells expressing ACTH, prolactin, or LHB transcripts in the mouse anterior pituitary (Westphal et al. 2009), consistent with the expression of CRHR1 in the mouse gonadotropelike $\alpha \mathrm{T} 3-1$ cell line. CRHR 2 expression in the rodent is quite distinct from CRHR1, with a more restricted pattern in the brain but numerous sites of expression in the periphery (Chalmers et al. 1996, Van Pett et al. 2000). While the two rodent isoforms of CRHR2, CRHR $2 \alpha$ and CRHR2 $\beta$, show comparable pharmacological properties (Hauger et al. 2006), they differ significantly in their tissue-specific expression. In situ hybridization studies using probes from the common region of CRHR2 have demonstrated Crhr2 mRNA expression in the posterior pituitary, with a weak but clearly detectable signal in the anterior pituitary (Van Pett et al. 2000), most likely in gonadotropes (Kageyama et al. 2003). CRHR $2 \alpha$ mRNA has also been detected in anterior pituitary by ribonuclease protection assay (Kageyama et al. 2003). Consistent with these results, we have detected CRHR $2 \alpha$ mRNA, but not CRHR $2 \beta$, in $\alpha \mathrm{T} 3-1$ cells by RT-PCR. Together, these results suggest that a population of gonadotropes may express both CRHR 1 and CRHR $2 \alpha$ at certain times in development or in response to specific hormonal signals.

The expression of CRHR 1 and CRHR $2 \alpha$ on $\alpha$ T3- 1 cells that also express GNRH1 receptors is quite interesting in light of the recent studies demonstrating the significant population of anterior pituitary cells in rat and mouse that exhibit multiple hypothalamic releasing hormone (HRH) receptors (multi-responsive cells; Nunez et al. 2003, Villalobos et al. 2004). Recent studies have suggested that $38 \%$ of female mouse anterior pituitary cells express multiple HRH receptors, with almost $50 \%$ of LHB-positive cells being multi-responsive (Nunez et al. 2003). Our results are consistent with these studies and suggest that anterior pituitary cells are more multifunctional than previously thought, with great potential for crosstalk between HRH and pituitary hormonal release. Interestingly, CRH has recently been shown to induce thyrotropin release from the amphibian pituitary gland via CRHR2 signaling (Okada et al. 2007).

In response to treatment with $\mathrm{CRH}$ or $\mathrm{UCN}$, the $\alpha \mathrm{T} 3-1$ cells show a very rapid increase in the intracellular cAMP levels, demonstrating the positive coupling of the $\mathrm{CRH}$ receptors to $G_{s}$ and adenylyl cyclase after ligand stimulation. The rapid rise in the intracellular cAMP levels in $\alpha \mathrm{T} 3-1$ cells in response to CRH or UCN with a peak at $2-5 \mathrm{~min}$ followed by a rapid decline is similar to the results seen with murine atrial cardiomyocyte tumor cells, AT-1 cells, which express endogenous CRHR $2 \beta$ mRNA (Heldwein et al. 1996). The rapid decline in the cAMP levels even in the 
presence of IBMX is quite interesting, and it may suggest that one or both types of CRH receptors on $\alpha \mathrm{T} 3-1$ cells are desensitized quickly following exposure to ligand. This theory is supported by the reports of rapid agonist-induced CRHR1 desensitization and internalization (Roseboom et al. 2001, Teli et al. 2005). Alternatively, the dose of IBMX used in these studies may not be sufficient to inhibit all phosphodiesterase activity in these cells.

The responses to CRH and the urocortins in the $\alpha \mathrm{T} 3-1$ cells were dose dependent and specific for CRH receptors, as the presence of non-selective CRH receptor antagonists, $\boldsymbol{\alpha}$-helical CRH 9-41 or AST, completely inhibited the intracellular cAMP increases. Similar peak cAMP values were observed with CRH or UCN, ligands that activate both CRHR 1 and CRHR2 $\alpha$. By contrast, peak cAMP values with UCN2 and UCN3 stimulation reached levels only 50-60\% of UCN- or CRH-stimulated levels, consistent with their CRHR2 selectivity. Similarly, the significant, but incomplete, inhibition of UCN-mediated increases in cAMP production in $\alpha$ T3-1 cells with antisauvagine, the CRHR2-specific antagonist (100- to 400-fold greater binding to CRHR2), was consistent with the UCNmediated activation of both CRHR 1 and CRHR $2 \alpha$. The EC50 values for cAMP production in $\alpha \mathrm{T} 3-1$ cells were not significantly different between CRH, UCN, UCN2, or $\mathrm{UCN} 3$, and ranged from 14 to $32 \mathrm{nM}$. Studies in cell lines that have been stably or transiently transfected with $\mathrm{CRH}$ receptors have shown EC50 values for CRHR1 of 1-3 nM for both CRH and UCN and EC50 values for CRHR2 of 0.2-20 nM (Vaughan et al. 1995). Primary cultures or cultured cell lines expressing endogenous $\mathrm{CRH}$ receptors have shown higher EC50 values (Heldwein et al. 1996).

While stress-induced suppression of GNRH1 and LHB release is clearly dependent on central actions of $\mathrm{CRH}$ (Li et al. 2005, 2006), the finding that $\alpha \mathrm{T} 3-1$ cells, a gonadotrope-like cell line, express CRH receptors suggests an additional and potential direct role for $\mathrm{CRH}$ or urocortins on gonadotrope function, consistent with the recent studies that have identified Crhr1 or Crhr2 mRNA in rat or mouse gonadotropes (Kageyama et al. 2003, Westphal et al. 2009). Our studies here extend the previous results to demonstrate that these $\mathrm{CRH}$ receptors are functional, increasing the intracellular cAMP levels resulting in transcriptional activation of cAMP-responsive genes including the glycoprotein hormone $\boldsymbol{\alpha}$-subunit. PACAP has also been shown to increase cAMP levels in $\alpha$ T3-1 cells, resulting in increased $\alpha$-subunit expression (Schomerus et al. 1994, Tsujii et al. 1995, Attardi \& Winters 1998). Interestingly, while GNRH1 does not alter cAMP levels in $\alpha \mathrm{T} 3-1$ cells, GNRH1 significantly reduces the PACAP-mediated increase in cAMP levels via the activation of the PKC signaling pathway (McArdle et al. 1994, McArdle \& Counis 1996), emphasizing the importance of crosstalk between distinct intracellular signaling pathways in these gonadotrope-like cells. It is possible that GNRH1 may also modify the CRH-mediated increases in cAMP in these cells. Similarly, we have initiated preliminary studies of
GNRH1 signaling and phospholipase C (PLC) activation in aT3-1 cells. While GNRH1 treatment dramatically increases total inositol phosphate levels via PLC activation, CRH treatment alone has no significant effect on inositol phosphate levels (unpublished data, A. Seasholtz). However, if CRH and GNRH1 are co-administered, CRH significantly decreases the GNRH1-mediated increases in inositol phosphates, showing another level of crosstalk between the PKA and $\mathrm{PLC} / \mathrm{PKC}$ signaling pathways in these gonadotrope-like cells (unpublished data, A. Seasholtz). Functional interactions between the PKA and PLC/PKC systems have also been observed in the L $\beta$ T2 gonadotrope-like cell line, with GNRH1 stimulating PACAP receptor phosphorylation by PKC (Lariviere et al. 2008). Hence, while $\alpha$ T3-1 cells represent only a model of gonadotrope function, these studies suggest that CRH receptor signaling on pituitary gonadotropes may contribute, along with other peptide and gonadal hormones, to the modulation of GNRH1 signaling at these cells and resultant gonadotropin synthesis and release.

Finally, it should also be noted that the CRH-binding protein (CRHBP) is highly expressed in rodent anterior pituitary (Speert et al. 2002). This secreted glycoprotein binds CRH and UCN with high affinity and is thought to act largely as an inhibitory protein, binding the ligands and decreasing CRH receptor activation (reviewed in Westphal \& Seasholtz (2006)). CRHBP expression is positively regulated by estrogen, resulting in a sexually dimorphic pattern of expression with CRHBP detected in corticotropes in male mice, while it is detected in corticotropes, lactotropes, and gonadotropes in female mice (Speert et al. 2002). CRHBP is also expressed in $\alpha$ T3-1 cells where its expression is regulated by GNRH1 (Westphal \& Seasholtz 2005). Hence, the actions of CRH and UCN on $\alpha \mathrm{T} 3-1$ cells or gonadotropes in vivo may be highly regulated by the pituitary CRHBP.

In conclusion, we have demonstrated that $\alpha \mathrm{T} 3-1$ cells express Crhr1 and CRHR2 $\alpha$ mRNAs and that these CRH receptors are functionally coupled to the Gs signal transduction pathways. These receptors respond to $\mathrm{CRH}$, UCN, UCN2, or UCN3 treatment with rapid, transient increases in intracellular cAMP levels, and CRH receptor antagonist data confirm the contributions of both CRHR 1 and CRHR2 to the cAMP inductions. The activation of these receptors also increases the transcriptional activity of the glycoprotein hormone $\boldsymbol{\alpha}$-subunit promoter, a well-characterized cAMPresponsive promoter. Since $\alpha \mathrm{T} 3-1$ cells serve as a model for gonadotrope cells, these data suggest a potential direct role for $\mathrm{CRH}$ or the other CRH-like ligands, UCN, UCN2, and UCN3, in the coordinated control of gonadotropin expression and secretion at the gonadotrope. Studies in primary mouse anterior pituitary cultures and in vivo will allow us to further examine the actions of $\mathrm{CRH}$ and urocortins (and the CRHBP) on both basal and stimulated pituitary hormone release, potentially revealing new roles for these ligands in pituitary function. 


\section{Declaration of interest}

The authors have no conflict of interest to report.

\section{Funding}

The studies were supported by NIH grants DK54323 to R C T and DK42730 and DK57660 to A F S We gratefully acknowledge the postdoctoral support of M Öhman from the Academy of Finland (grant no. 52840) and the Finnish Medical Foundation.

\section{Acknowledgements}

We would like to thank Linda Harper Gates and Jyoti Kothavale for their assistance with $\alpha$ T3-1 studies. This work was presented in part at the 85 th Annual Meeting of the Endocrine Society, Philadelphia, PA. While this manuscript was under revision, a separate manuscript from our laboratory was published, which documented $\mathrm{CRH}$ receptor expression in multiple anterior pituitary cells lines (including $\alpha \mathrm{T} 3-1$ cells) and in murine corticotropes, lactotropes, and gonadotropes (Westphal et al. 2009).

\section{References}

Attardi B \& Winters SJ 1998 Transcriptional regulation of the glycoprotein hormone alpha-subunit gene by pituitary adenylate cyclase-activating polypeptide (PACAP) in alphaT3-1 cells. Molecular and Cellular Endocrinology 137 97-107.

Baldwin HA, Rassnick S, Rivier J, Koob GF \& Britton KT 1991 CRF antagonist reverses the 'anxiogenic' response to ethanol withdrawal in the rat. Psychopharmacology 103 227-232.

Bale TL \& Vale WW 2004 CRF and CRF receptors: role in stress responsivity and other behaviors. Annual Review of Pharmacology and Toxicology $\mathbf{4 4}$ 525-557.

Blank MS, Fabbri A, Catt KJ \& Dufau ML 1986 Inhibition of luteinizing hormone release by morphine and endogenous opiates in cultured pituitary cells. Endocrinology 118 2097-2101.

Brauns O, Brauns S, Jenke M, Zimmermann B \& Dautzenberg F 2002 Secondary structure of antisauvagine analogues is important for CRF receptor antagonism: development of antagonists with increased potency and receptor selectivity. Peptides 23 1817-1827.

Brinkmeier ML, Gordon DF, Dowding JM, Saunders TL, Kendall SK, Sarapura VD, Wood WM, Ridgway EC \& Camper SA 1998 Cell-specific expression of the mouse glycoprotein hormone alpha-subunit gene requires multiple interacting DNA elements in transgenic mice and cultured cells. Molecular Endocrinology 12 622-633.

Burrin JM, Aylwin SJ, Holdstock JG \& Sahye U 1998 Mechanism of action of pituitary adenylate cyclase-activating polypeptide on human glycoprotein hormone alpha-subunit transcription in alphaT3-1 gonadotropes. Endocrinology 139 1731-1737.

Chalmers DT, Lovenberg TW \& De Souza EB 1995 Localization of novel corticotropin-releasing factor receptor (CRF2) mRNA expression to specific subcortical nuclei in rat brain: comparison with CRF1 receptor mRNA expression. Journal of Neuroscience 15 6340-6350.

Chalmers DT, Lovenberg TW, Grigoriadis DE, Behan DP \& De Souza EB 1996 Corticotrophin-releasing factor receptors: from molecular biology to drug design. Trends in Pharmacological Sciences 17 166-172.

Chen A, Perrin M, Brar B, Li C, Jamieson P, Digruccio M, Lewis K \& Vale W 2005 Mouse corticotropin-releasing factor receptor type 2alpha gene: isolation, distribution, pharmacological characterization and regulation by stress and glucocorticoids. Molecular Endocrinology 19 441-458.

Cortright DN, Goosens KA, Lesh JS \& Seasholtz AF 1997 Isolation and characterization of the rat corticotropin-releasing hormone (CRH)binding protein gene: transcriptional regulation by cyclic adenosine monophosphate and CRH. Endocrinology 138 2098-2108.
Dautzenberg FM \& Hauger RL 2002 The CRF peptide family and their receptors: yet more partners discovered. Trends in Pharmacological Sciences $\mathbf{2 3}$ 71-77.

Donaldson C, Sutton S, Perrin M, Corrigan A, Lewis K, Rivier J, Vaughan J \& Vale W 1996 Cloning and characterization of human urocortin [published erratum appears in Endocrinology 1996 Sep;137(9)3896. Endocrinology 137 2167-2170.

Dunn AJ \& Berridge CW 1990 Physiological and behavioral responses to corticotropin-releasing factor administration: is CRF a mediator of anxiety or stress responses? Brain Research. Brain Research Reviews 15 71-100.

Evans JJ 1999 Modulation of gonadotropin levels by peptides acting at the anterior pituitary gland. Endocrine Reviews 20 46-67.

Grammatopoulos DK \& Chrousos GP 2002 Functional characteristics of $\mathrm{CRH}$ receptors and potential clinical applications of $\mathrm{CRH}$-receptor antagonists. Trends in Endocrinology and Metabolism 13 436-444.

Hauger RL, Risbrough V, Brauns O \& Dautzenberg FM 2006 Corticotropin releasing factor (CRF) receptor signaling in the central nervous system: new molecular targets. CNS and Neurological Disorders Drug Targets 5 453-479.

Heldwein KA, Redick DL, Rittenberg MB, Claycomb WC \& Stenzel-Poore MP 1996 CRH receptor expression and functional coupling in neonatal cardiac myocytes and AT-1 cells. Endocrinology 137 3631-3639.

Hillhouse E \& Grammatopoulos D 2006 The molecular mechanisms underlying the regulation of the biological activity of $\mathrm{CRH}$ receptors: implications for physiology and pathophysiology. Endocrine Reviews $\mathbf{2 7}$ 260-286.

Horn F, Bilezikjin LM, Perrin MH, Bosma MM, Windle JJ, Huber KS, Blount A, Hille B, Vale W \& Mellon P 1991 Intracellular responses to gonadotropin-releasing hormone in a clonal cell line of the gonadotrope lineage. Molecular Endocrinology 5 347-355.

Hsu S \& Hsueh AJW 2001 Human stresscopin and stresscopin-related peptide are selective ligands for the type 2 corticotropin-releasing hormone receptor. Nature Medicine 7 605-611.

Jahn O, Tezval H, van Werven L, Eckart K \& Spiess J 2004 Three-amino acid motifs of urocortin II and III determine their CRF receptor subtype selectivity. Neuropharmacology $47233-242$.

Kageyama K, Li C \& Vale W 2003 CRF receptor type 2 mRNA in rat pituitary: localization and regulation by immune challenge, restraint stress, and glucocorticoids. Endocrinology 144 1524-1532.

Lariviere S, Garrel-Lazayres G, Simon V, Shintani N, Baba A, Counis R \& Cohen-Tannoudji J 2008 Gonadotropin-releasing hormone inhibits pituitary adenylyl cyclase-activating polypeptide coupling to $3^{\prime}, 5^{\prime}$-cyclic adenosine- $5^{\prime}$-monophosphate pathway in L $\beta \mathrm{T} 2$ gonadotrope cells through novel protein kinase $\mathrm{C}$ isoforms and phosphorylation of pituitary adenylyl cyclase-activating polypeptide type I receptor. Endocrinology 149 6389-6398.

Lewis K, Li C, Perrin MH, Blount A, Kunitake J, Donaldson C, Vaughan J, Reyes TM, Gulyas J, Fischer W et al. 2001 Identification of urocortin III, an additional member of the corticotropin-releasing factor (CRF) family with high affinity for the CRF2 receptor. PNAS $\mathbf{9 8} 7570-7575$.

Li XF, Bowe JE, Lightman SL \& O'Byrne KT 2005 Role of corticotropinreleasing factor receptor-2 in stress-induced suppression of pulsatile luteinizing hormone secretion in the rat. Endocrinology 146 318-322.

Li XF, Bowe JE, Kinsey-Jones JS, Brain SD, Lightman SL \& O’Byrne KT 2006 Differential role of corticotrophin-releasing factor receptor types 1 and 2 in stress-induced suppression of pulsatile luteinising hormone secretion in the female rat. Journal of Neuroendocrinology 18 602-610.

Lovenberg TW, Chalmers DT, Liu C \& DeSouza EB 1995a CRF2a and CRF2b receptor mRNAs are differentially distributed between the rat central nervous system and peripheral tissues. Endocrinology 136 4139-4142.

Lovenberg TW, Liaw CW, Grigoriadis DE, Clevanger W, Chalmers DT, De Souza EB \& Oltersdorf T $1995 b$ Cloning and characterization of a functionally distinct CRF receptor subtype from rat brain. PNAS 92 836-840.

Maeda K, Cagampang FR, Coen CW \& Tsukamura H 1994 Involvement of the catecholaminergic input to the PVN and of CRH in the fasting induced suppression of LH release in female rats. Endocrinology 134 1718-1722. 
McArdle CA \& Counis R 1996 GnRH and PACAP action in gonadotropes cross-talk between phosphoinositidase $\mathrm{C}$ and adenylyl cyclase mediated signaling pathways. Trends in Endocrinology and Metabolism 7 168-175.

McArdle CA, Poch A, Schomerus E \& Kratzmeier M 1994 Pituitary adenylate cyclase-activating polypeptide effects in pituitary cells: modulation by gonadotropin-releasing hormone in alpha T3-1 cells. Endocrinology 134 2599-2605.

Nunez L, Villalobos C, Senovilla L \& Garcia-Sancho J 2003 Multifunctional cells of mouse anterior pituitary reveal a striking sexual dimorphism. Journal of Physiology 549 835-843.

Okada R, Miller MF, Yamamoto K, De Groef B, Denver RJ \& Kikuyama S 2007 Involvement of the corticotropin-releasing factor (CRF) type 2 receptor in CRF-induced thyrotropin release by the amphibian pituitary gland. General and Comparative Endocrinology 150 437-444.

Owens MJ \& Nemeroff CB 1991 Physiology and pharmacology of corticotropin-releasing factor. Pharmacological Reviews 43 425-473.

Van Pett K, Viau V, Bittencourt JC, Chan RK, Li HY, Arias C, Prins GS, Perrin M, Vale WW \& Sawchenko PE 2000 Distribution of mRNAs encoding CRF receptors in brain and pituitary of rat and mouse. Journal of Comparative Neurology 428 191-212.

Potter E, Sutton S, Donaldson C, Chen R, Perrin M, Lewis K, Sawchenko PE \& Vale W 1994 Distribution of corticotropin-releasing factor receptor mRNA expression in the rat brain and pituitary. PNAS 91 8777-8781.

Reyes TM, Lewis K, Perrin M, Kunitake KS, Vaughan J, Arias CA, Hogenesch JB, Gulyas J, Rivier J, Vale WW et al. 2001 Urocortin II: a member of the corticotropin-releasing factor (CRF) neuropeptide family that is selectively bound by type 2 CRF receptors. PNAS $\mathbf{9 8} 2843-2848$.

Rivest S \& Rivier C 1995 The role of CRF and interleukin-1 in the regulation of neurons controlling reproductive functions. Endocrine Reviews 16 177-200.

Rivier C \& Vale W 1984 Influence of corticotropin-releasing factor on reproductive functions in the rat. Endocrinology 114 914-919.

Roseboom PH, Urben CM \& Kalin NH 2001 Persistent corticotropinreleasing factor(1) receptor desensitization and downregulation in the human neuroblastoma cell line IMR-32. Brain Research. Molecular Brain Research 92 115-127.

Ruhmann A, Bonk I, Lin CR, Rosenfeld MG \& Spiess J 1998 Structural requirements for peptidic antagonists of the corticotropin-releasing factor receptor (CRFR): develoment of CRFR2b-selective antisauvagine-30. PNAS 95 15264-15269.

Schoderbek WE, Kim KE, Ridgway EC, Mellon PL \& Maurer RA 1992 Analysis of DNA sequences required for pituitary-specific expression of the glycoprotein hormone alpha-subunit gene. Molecular Endocrinology 6 893-903.
Schomerus E, Poch A, Bunting R, Mason WT \& McArdle CA 1994 Effects of pituitary adenylate cyclase-activating polypeptide in the pituitary: activation of two signal transduction pathways in the gonadotrope-derived alpha T3-1 cell line. Endocrinology 134 315-323.

Speert DB, SJ MC \& Seasholtz AF 2002 Sexually dimorphic expression of corticotropin-releasing hormone-binding protein in the mouse pituitary. Endocrinology 143 4730-4741.

Teli T, Markovic D, Levine MA, Hillhouse EW \& Grammatopoulos DK 2005 Regulation of corticotropin-releasing hormone receptor type 1alpha signaling: structural determinants for $G$ protein-coupled receptor kinasemediated phosphorylation and agonist-mediated desensitization. Molecular Endocrinology 19 474-490.

Tsujii T, Attardi B \& Winters SJ 1995 Regulation of alpha-subunit mRNA transcripts by pituitary adenylate cyclase-activating polypeptide (PACAP) in pituitary cell cultures and alpha T3-1 cells. Molecular and Cellular Endocrinology 113 123-130.

Vaughan J, Donaldson C, Bittencourt J, Perrin MH, Lewis K, Sutton S, Chan R, Turnbull AV, Lovejoy D, Rivier C et al. 1995 Urocortin, a mammalian neuropeptide related to fish urotensin I and to corticotropin-releasing factor. Nature 378 287-292.

Villalobos C, Nunez L \& Garcia-Sancho J 2004 Anterior pituitary thyrotropes are multifunctional cells. American Journal of Physiology. Endocrinology and Metabolism 287 E1166-E1170.

Westphal NJ \& Seasholtz AF 2005 Gonadotropin-releasing hormone (GnRH) positively regulates corticotropin-releasing hormone-binding protein expression via multiple intracellular signaling pathways and a multipartite GnRH response element in alphaT3-1 cells. Molecular Endocrinology 19 2780-2797.

Westphal NJ \& Seasholtz AF 2006 CRH-BP: the regulation and function of a phylogenetically conserved binding protein. Frontiers in Bioscience $\mathbf{1 1}$ 1878-1891.

Westphal NJ, Evans RT \& Seasholtz AF 2009 Novel expression of type 1 $\mathrm{CRH}$ receptor in multiple endocrine cell types in the murine anterior pituitary. Endocrinology 150 260-267.

Windle JJ, Weiner RI \& Mellon PL 1990 Cell lines of the pituitary gonadotrope lineage derived by targeted oncogenesis in transgenic mice. Molecular Endocrinology 4 597-603.

Received in final form 22 October 2008

Accepted 11 November 2008

Made available online as an Accepted Preprint 13 November 2008 